\title{
Identification of the Kukersite-type source rocks in the Ordovician Stratigraphy from the Tarim Basin, NW China
}

\author{
SUN YongGe $e^{1,2^{*}}$, MAO Sheng Yi ${ }^{1,4}$, WANG FeiYu ${ }^{3}$, PENG PingAn $^{1} \&$ CHAI PingXia $^{1}$ \\ ${ }^{1}$ State Key Laboratory of Organic Chemistry, Guangzhou Institute of Geochemistry, Chinese Academy of Sciences, Guangzhou 510640, China; \\ ${ }^{2}$ Department of Earth science, Zhejiang University, Hangzhou 310037, China; \\ ${ }^{3}$ Department of Geosciences, China University of Petroleum (Beijing), Beijing 102200, China; \\ ${ }^{4}$ University of Chinese Academy of Sciences, Beijing 100049, China
}

Received February 28, 2013; accepted May 14, 2013; published online July 11, 2013

\begin{abstract}
Due to the importance of the Gloeocapsomorpha Prisca (G. prisca)-enriched source rocks, which belong to Kukersite-type source rocks in the Lower Paleozoic Ordovician strata, it has received great attentions during the petroleum exploration as to whether there are the Kukersite-type source rocks developed in the major hydrocarbon source strata of the Upper and Middle Ordovician in the Tarim Basin. Using pyrolysis-gas chromatography-mass spectrography to analyse kerogens from source rocks in the limemud mound with moderate maturity, study reveals that there are the Kukersite-type source rocks in the Ordovician strata of the Tarim Basin. The pyrolysis products showed a low content of $>n-\mathrm{C}_{19}$ normal alkanes with a significant odd-even predominance between $n$ - $\mathrm{C}_{13}$ and $n-\mathrm{C}_{17}$, long-chain alky substituted alkylbenzene and alkylthiophene isomers and distinctive distribution of 5-Nalkyl-1, 3-Benzenediol and its homologous. Based on the geographic environment characteristics of G. Prisca, the molecular distributions of crude oil from the Lower Paleozoic petroleum systems in the Tarim Basin and characteristics of kerogen pyrolysis products from the Middle and Upper Ordovician source rocks, the results suggested that it is less possible to develop the G. Pris$c a$-enriched Kukersite-type source rocks in the major hydrocarbon source rocks in the Middle and Upper Ordovician strata in the Tarim Basin. However, the benthic macroalga and planktonic algae-enriched source rocks are the main contributors.
\end{abstract}

Tarim Basin, Kukersite-type source rocks, Ordovician Stratigraphy, kerogens, Gloeocapsomorpha Prisca

Citation: Sun Y G, Mao S Y, Wang F Y, et al. Identification of the Kukersite-type source rocks in the Ordovician Stratigraphy from the Tarim Basin, NW China. Chin Sci Bull, 2013, 58: 4450-4458, doi: 10.1007/s11434-013-5963-3

According to the petroleum exploration practices, the Paleozoic Ordovician marine sediments are an important series of petroleum source rocks in the world. The bio-precursors of hydrocarbon can be divided into two types. The first type is related to the Gloeocapsomorpha prisca (G. prisca), which belongs to Type I organic matter. It is called Kukersite-type source rock [1-3]. The other is type II amorphous organic matter, which is characterized by visible Acritarch, Chitinozoan, Scolecedont and graphtolite fossils in the rock $[3,4]$. The crude oil contributed by G. prisca usually has distinctive molecular geochemical fingerprint. In another word, there is odd-carbon number predominance such as

*Corresponding author (email: ygsun@zju.edu.cn)
$n-\mathrm{C}_{15}, n-\mathrm{C}_{17}$ and $n-\mathrm{C}_{19}$ in $\mathrm{N}$-alkanes with low carbon numbers; meanwhile the relevant content of $\mathrm{N}$-alkanes with high carbon numbers is very less [1-13]. According to the statistics, Kukersite-type source rocks are the primary contributor of petroleum resources of the Lower Paleozoic marine petroleum field that is discovered in north American platform, including the G. prisca-enriched and G. prisca-diluted types [11].

The Yakela petroleum field was found in 1984. It has become the biggest palaeozoic marine oil field (Tahe-Lunnan 100 million ton oil field) as a result of large-scale explorations of 30 years in the Tarim Basin. Due to the importance of Ordovician marine source rocks in the global exploration of Paleozoic petroleum resources and the con- 
sideration of the actual results of the basin biomarker oilsource correlation of compounds, most geochemists believe that the Middle and Upper Ordovician source rocks are the major source rocks of marine crude oil in the Tarim Basin [14-20]. There are a great amount of geochemical evidences such as molecules and isotope that prove the fact that the Cambrian-Lower Ordovician source rocks had significant contributions to the Lower Paleozoic petroleum systems which have been found so far [21-25]. Although there are still some differences in the understanding of oil field, one of the preconditions of Ordovician marine sedimentary layer as a major oil source rocks is that the source rocks have to be plentiful in hydrogen-enriched organic matters. According to the foreign exploration experiences, it is generally believed that the Ordovician source rocks are biogenically monotonic. It mainly consists of biological species of hydrogen-rich homonemeae, of which most are related to the development of Kukersite-type source rocks. For this reason, whether there is a growth of Kukersite-type source rocks in the Ordovician marine sedimentary strata in the Tarim Basin has become a question which is always asked by the Chinese specialists and explorers of petroleum and geochemistry. The exploration of this matter has directive significance to the search of high quality marine source rocks of Ordovician in the Tarim Basin.

Over the last ten years, it is initially revealed that there is a possibility that the Kukersite-type source rocks indeed exist in the Tazhong area of the Tarim Basin in view of sedimentary facies and morphology [19]. In this study, 11 Middle and Upper Ordovician source rocks of interdune depressions, which possibly consist of Kukersite-type source rocks, were selected out from the geochemistry database of source rock samples developed by the Tarim Basin Petroleum Exploration Brainstorm Project from the "Ninth Fiveyear Plan" of China. With the application of pyrolysis gas chromatograph/mass spectrogram technology, the characteristic biomarker compounds which indicated the biogenic source of $G$. prisca were tested thoroughly from the kerogen pyrolysis products. In addition, a discussion was carried out on the possible indicative significance of the distributive features of samples' characteristic compounds in petroleum geology.

\section{Research sample and experimental condition}

Based on previous research results, representative samples of the Middle and Upper Ordovician strata from Tazhong Area mainly consisting of sediments of Lianglitage Formation were selected. The source rocks were developed in the sediments of lime-mud mound facies, including the interdune depression and lime-mud mound-core facies. In the meantime, a comparative analysis was carried out on the Lower Ordovician source rocks of undercompensated estuarine sedimentary facies in Dawangou Saergan section (Table 1).
After the process of separation and beneficiation, samples of kerogens were obtained, after which benzene-methanolacetone ternary solvent were applied for the on-line pyrolysis GC-MS analysis after one week. Then, about $1 \mathrm{mg}$ kerogen sample was put in the CDS system of Pyroprobe Model 2000 to be warmed up to $250^{\circ} \mathrm{C}$. The sample was kept under such constant temperature for $5 \mathrm{~min}$ with the protection of inert gases in order to remove the remaining volatile free components in the kerogen. After that, the sample was heated up from $250^{\circ} \mathrm{C}$ to $770^{\circ} \mathrm{C}$ with a $5^{\circ} \mathrm{C} / \mathrm{min}$ heating rate and kept under such temperature for $10 \mathrm{~s}$. The pyrolysis products were directly brought into the Voyager 1000 mass spectrometry system of Carlo Erba GC 8000 TOP gas chromatography instrument by helium gas. For the chromatography separation, HP-1 elastic quartz capillary column (30 $\mathrm{m} \times 0.32 \mathrm{~mm} \times 0.25 \mu \mathrm{m})$ was applied. The initial temperature was $30^{\circ} \mathrm{C}$, which was kept unchanged for $5 \mathrm{~min}$. Then it was heated up until $300^{\circ} \mathrm{C}$ with a heating rate of $3^{\circ} \mathrm{C} / \mathrm{min}$ and remained for $15 \mathrm{~min}$. The carrier gas was helium gas, and the speed was $1.0 \mathrm{~mL} / \mathrm{min}$ constantly. In addition, the mass spectrometry conditions are as follows: $200^{\circ} \mathrm{C}$ ion source temperature, EI mode and $70 \mathrm{eV}$. The compound was identified in accordance with the references and the retention time.

\section{Results and discussion}

The study shows that, among numerous sedimentary facies types of the Middle and Upper Ordovician in the Tarim Basin, only the closed and undercompensated terrigenous bay, semi-closed and undercompensated terrigenous bay and lime-mud mound facies of platform margin slope contain source rocks with high abundance of organic matter. The distributions of the former two were limited at KepingAvati depression, and had limited contributions to the oil and gas reservoirs [19]. The detailed geochemical analysis of source rocks in Tazhong area has shown that the source rocks with high organic matter abundances in the Middle and Upper Ordovician are sediments of lime-mud mound facies of platform margin slope in principle. Among them, the interdune depression sediments have the highest level of organic matter abundance and are capable of developing high quality source rocks [19]. According to Table 1, it is clear that the sedimentary source rocks of interdune depression facies are obviously enriched with organic matter compared with that of the sediments of lime-mud mound-core facies. This reflects the strong heterogeneous characteristics of the sedimentary organic matters of lime-mud mound in another perspective. The maximum pyrolysis peak temperature of the organic matter in samples of source rock is around $440^{\circ} \mathrm{C}$, which shows that the present thermal metamorphic grade of source rock is at peak of the petroleum generation, which approximately equals to vitrinite reflectance of $\sim 1.0 \%$ Ro. This is consistent with the result of 
Table 1 Sample background and pyrolysis features

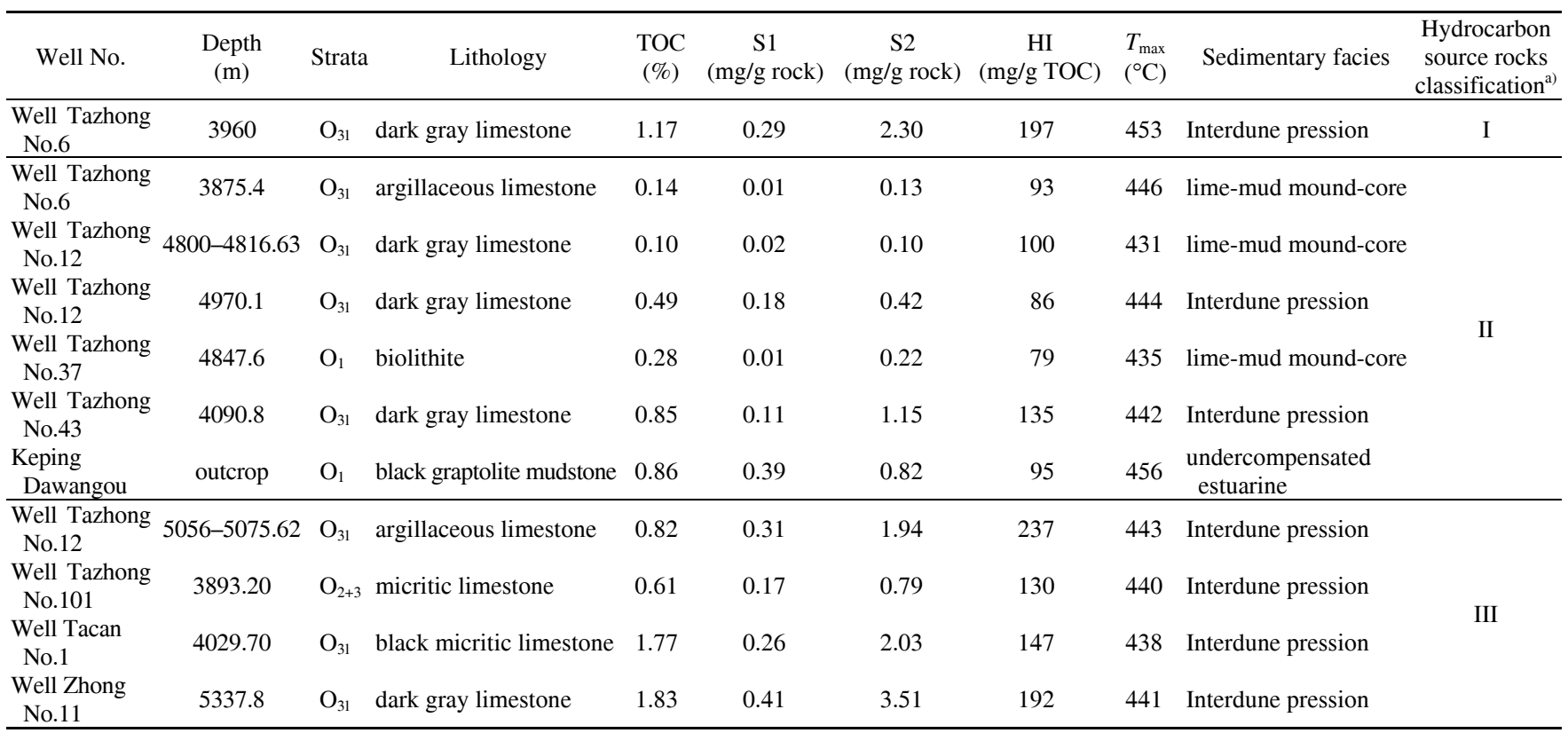

a) For hydrocarbon source rocks classification see the text.

conodont color index CAI and the reflection rate of vitrinitelike maceral [26]. Hence, the kerogen pyrolysis products in the period of thermal evolution could represent the biochemical compositions of the precursor of sedimentary organic matter [27].

\subsection{Identification of the $G$. Prisca's biogenic biomarker compounds in the kerogen pyrolysis products of the Middle and Upper Ordovician source rock}

There are two identification methods to check whether there is biogenic source of G. prisca in sedimentary organic matters. First, the distribution characteristics of $\mathrm{N}$-alkanes in the crude oil can be utilized in determination. In general, the factor that distinguishes the crude oil generated by Kukersite-type source rocks from others generated by organic matter is the odd-even predominance of low carbon number $\mathrm{N}$-alkane. In the meantime, the content of high carbon number $\mathrm{N}$-alkane is relatively low [1-13]. However, this feature has yet been found in the crude oil of the Lower Paleozoic petroleum system in the Tarim Basin [19]. As a second method, the molecular composition of kerogen pyrolysis products of source rocks can be adopted in identification. In general, the kerogen pyrolysis products of Kukersite-type sedimentary source rocks are characterized by the following features: low content of $>n-\mathrm{C}_{19}$ chain hydrocarbon, the oddeven predominance between the $n-\mathrm{C}_{9}$ and $n-\mathrm{C}_{19}$ chain hydrocarbons, the low content of acyclic isoprenoid compound, relatively high content of cycloalkane compounds, the distinctive alkylbenzene, the distribution of alkylthrophene series compounds and the oxygen-containing compounds such as Alkyl ketone, phenol, benzenediol and the like
$[8,10,11,28]$. The most typical one of them is the phenolic compounds. The structure of this type of compounds is very different from the phenolic structures of tannic matters of terrestrial originated plants, which could be considered as the distinctive biomarker of G. prisca [8]. The analysis results of kerogen pyrolysis products from 11 selected source rocks collected by this study reveal that the distinctive compositions of G. prisca's biogenic biomarker compounds have been detected in the kerogen pyrolysis products of three source rocks (Figure 1). By comparison, the kerogen pyrolysis products of the Lianglitage Formation source rocks from the depth of $3960 \mathrm{~m}$ in Well Tazhong No.6 are the most typical one. According to the figure, the normal chain hydrocarbons of pyrolysis products are mainly distributed in the parts with low carbon number. Based on the mass chromatogram of $\mathrm{m} / \mathrm{z} 55+57$ that shows the distribution of normal alkanes and normal olefine, the carbon number is from $n-\mathrm{C}_{8}$ to $n-\mathrm{C}_{19}$. Very few high number carbons are detected. But there is an obvious odd-even predominance between $n-\mathrm{C}_{13}$ and $n-\mathrm{C}_{17}$. There exists a high content of oxygenated compounds in the pyrolysis products, which are typically $G$. prisca's biomarker compounds (5-N-alkyl-1, 3 -Benzenediol and homologous compounds). The distinctive ions of such compound, including $\mathrm{m} / \mathrm{z}, 124,138$ and 152, depend on the numbers of methyl replacement on aromatic ring. However, there are still arguments on whether the methyl is directly bridged to the aromatic ring or connected with hydroxyl [8]. In the study, 5-N-alkyl-1,3-Benzenediol occupied the largest portion among all the oxygen compounds $(\mathrm{m} / \mathrm{z}, 124)$ detected, including its homologues with one degree of unsaturation and two degree of unsaturation. The carbon number distribution was from $C_{7}$ to $C_{23}$ but 

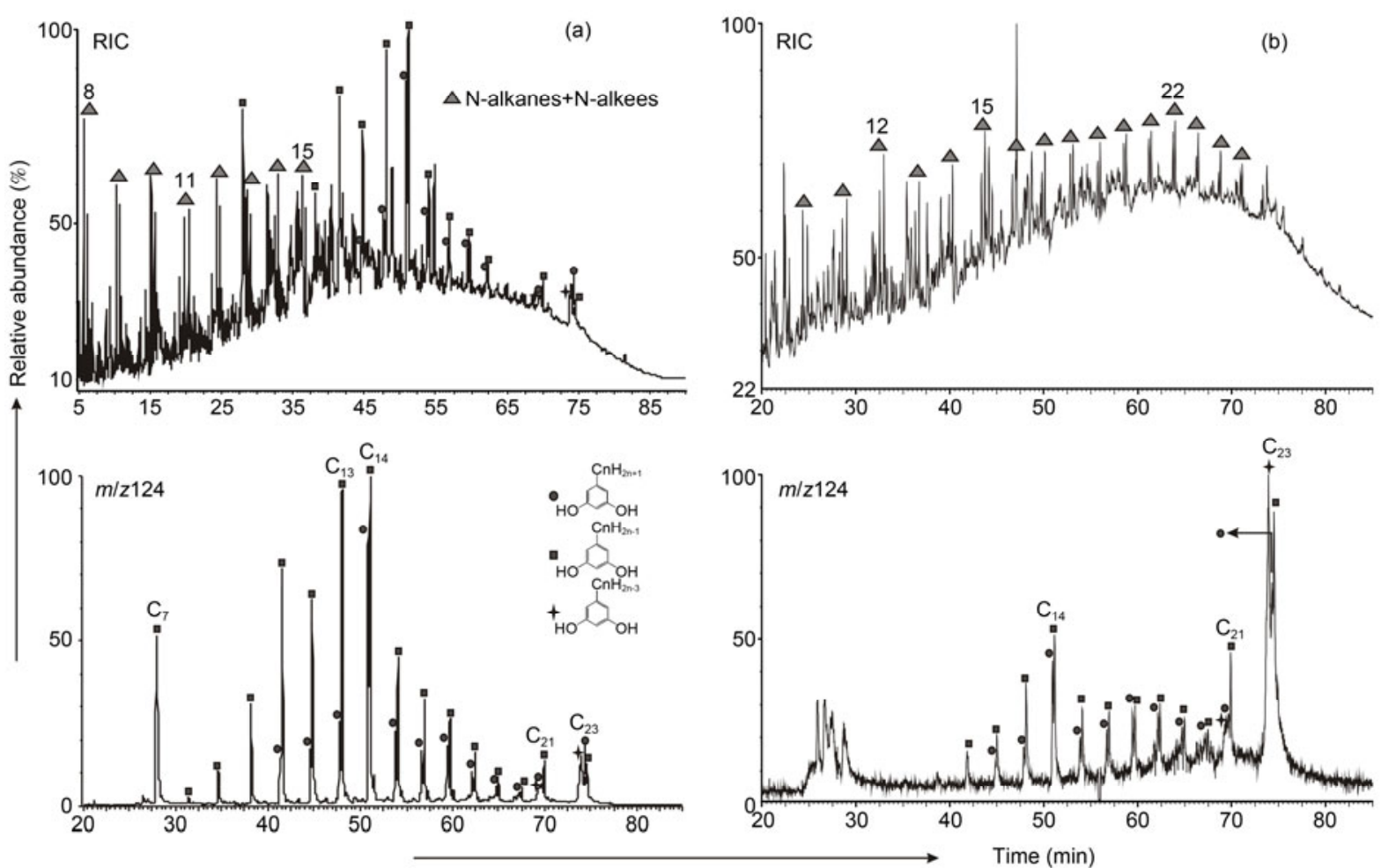

Figure 1 G. Prisca biomarker (5-N-alkyl-1,3-Benzenediol) and Homologous Compounds of the Kerogen pyrolysis Products of Middle and Upper Ordovician Source Rock, Well Tazhong No.6, 3960 m (a) and Well No.12, 4970.1 m (b). The numbers represent the number of carbon.

without $\mathrm{C}_{22}$. The main peak of 5-N-alkyl-1,3-Benzenediol as well as its homologue with one degree of unsaturation was $\mathrm{C}_{14}$ while another secondary peaks on $\mathrm{C}_{21}$ and $\mathrm{C}_{23}$ was also observed. But no peak emerged after $\mathrm{C}_{23}$. In the meantime, the distribution of compounds of alkylbenzene series (Figure 2) and alkylthrophene series (Figure 3) in pyrolysis products were characterized by the following features. First, the isomers were mainly replaced by the normal long chain alkyl. Second, the contents of other isomers were very low. Those features were almost completely identical with the kerogen pyrolysis products of Estonia Kukersite-type sedimentary source rocks $[8,10,28]$. Correspondingly, the existence of alginite which is like $G$. prisca in morphology was also observed by microscopy assay of kerogen (Figure 4). The pyrolysis results showed that such source rocks had a high abundance of organic matter $(\mathrm{TOC}=1.17 \%)$ and a

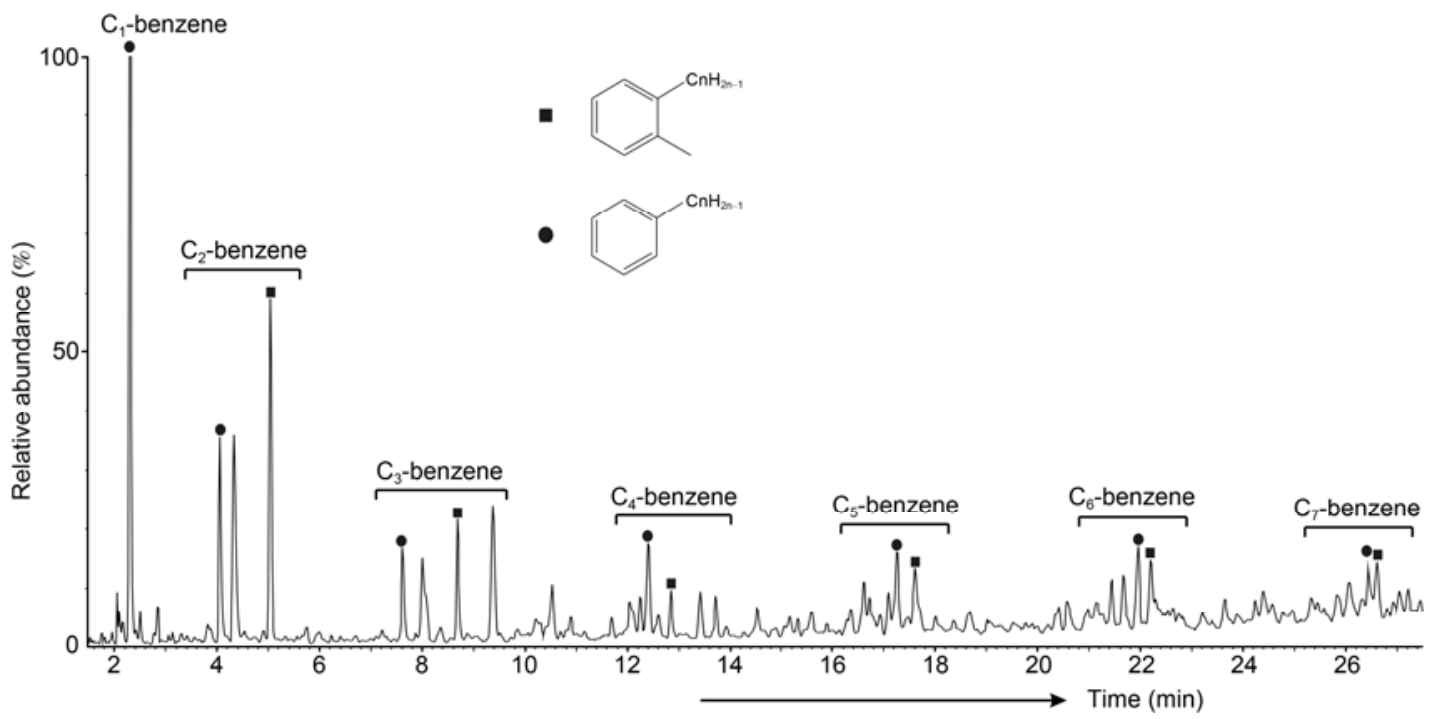

Figure 2 Distribution characteristics of the alkylbenzene series in the pyrolysis products of the organic matter of interdune depression facies source rock, Well Tazhong No.6, $3960 \mathrm{~m}$ depth. 


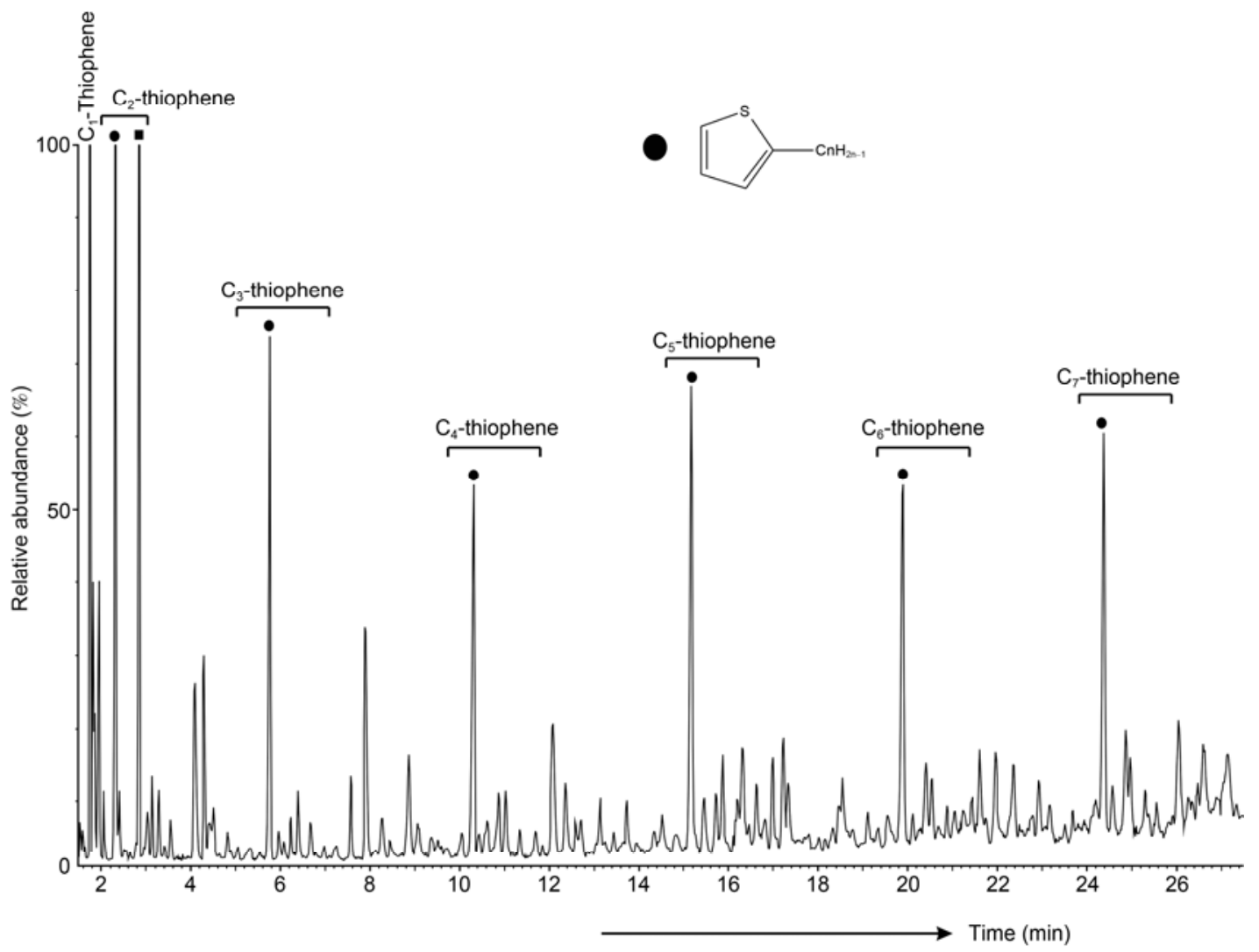

Figure 3 Characteristics of the alkylthrophene series compound in the pyrolysis products of the organic matter of interdune depression facies source rock, Well Tazhong No.6, $3960 \mathrm{~m}$ depth.

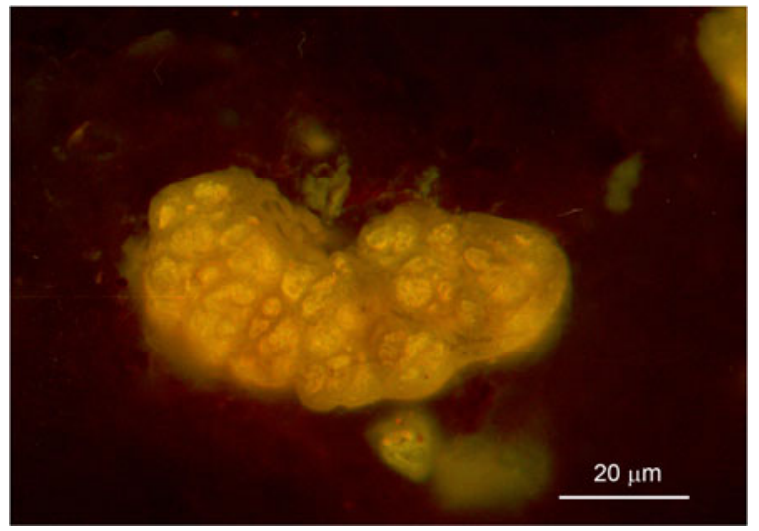

Figure 4 G. Prisca of interdune depression facies source rock, Well Tazhong No.6, $3960 \mathrm{~m}$ depth.

relatively high hydrogen index $\left(\mathrm{HI}=197 \mathrm{mg} / \mathrm{gTOC}, T_{\max }=\right.$ 453(C)). Hence, the Lianglitage Formation sediment from the depth of $3960 \mathrm{~m}$ of Well Tazhong No.6 could be identified as the Kukersite-type source rocks from three aspects: the overall characteristics of organic matter, the features of morphological organic matter and the features of molecular geochemistry. The other two source rocks that had two distinctive G. prisca biomarkers (5-N-alkyl-1,3-Benzenediol) and their homologous compounds showed none of the above typical molecular geochemical features. They possi- bly belonged to the diluted Kukersite-type source rocks (refer to the discussion below) [11].

\subsection{Composition characteristics of kerogen pyrolysis products of the Middle and Upper Ordovician source rocks and the indicative significance of corresponding hydrocarbon generation material}

According to results of the kerogen pyrolysis GC/MS analysis of the Middle and Upper Ordovician source rocks, the main pyrolysis products are normal alkane, normal ethylene series, benzene series, alkylbenzene series, phenol series, alkylthrophene series and terpenoids. From the perspective of hydrocarbon generation material, the Middle and Upper Ordovician source rocks could be divided into three types in accordance with the composition characteristics of the pyrolysis products of the source rocks (Figure 5). The first type could be distinguished as the Kukersite-type source rock, the sedimentary organic matter of which is mostly contributed by G. prisca. The identification mark of pyrolysis products is the distinctive G. prisca biomarker. In the meantime, the carbon number distribution of chain hydrocarbon is characterized by low carbon predominance. The $>n$ - $\mathrm{C}_{19}$ chain hydrocarbon is very low (Figure $5(\mathrm{a})$ ). Such source rocks have a high abundance of organic matter. Its hydrocarbon generating potential is large. The second type 
$\mathrm{RIC}$
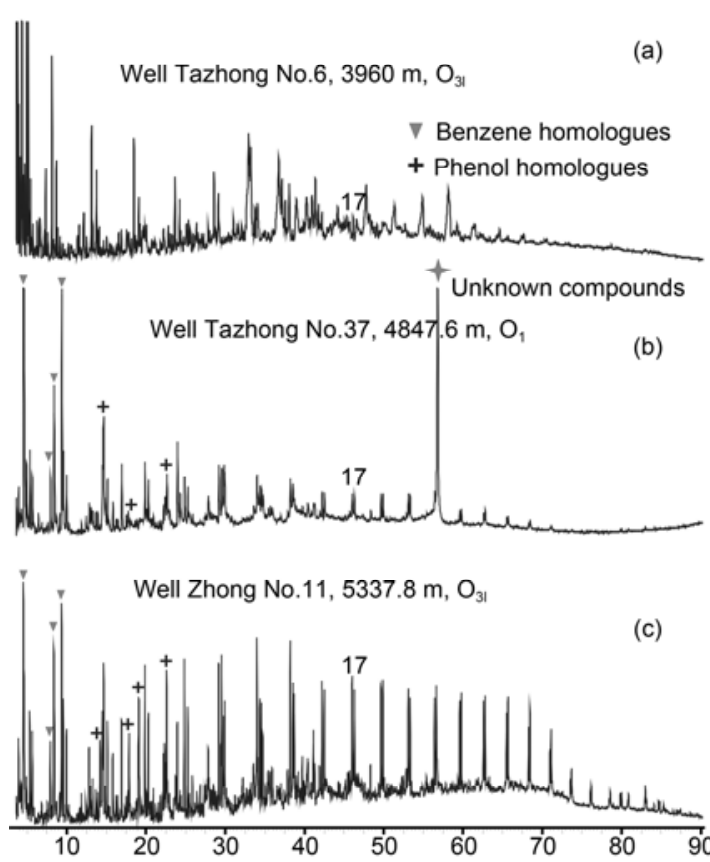
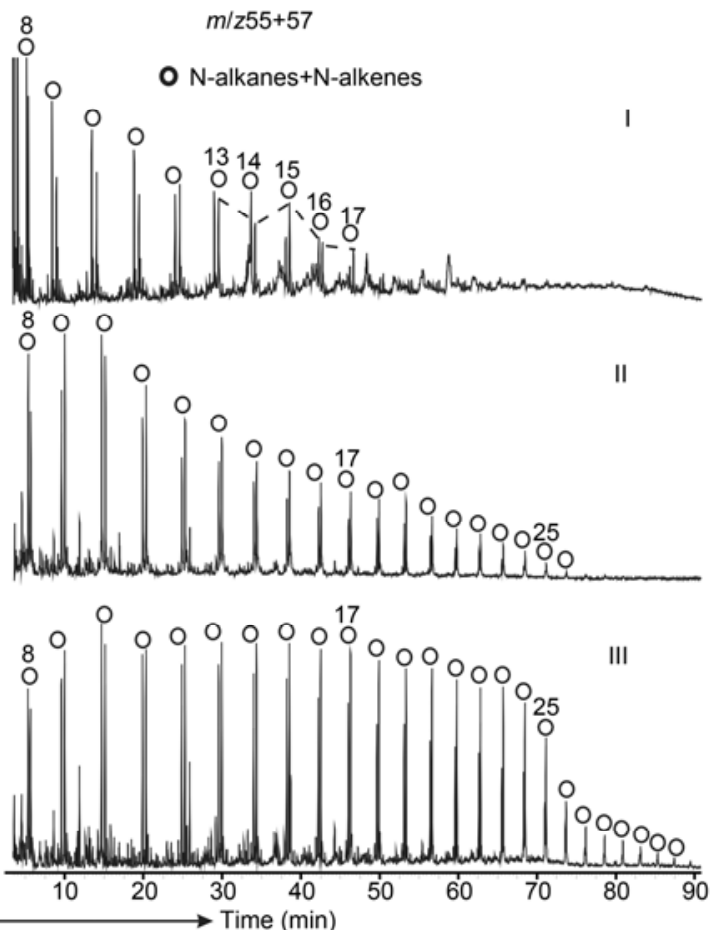

Figure 5 Characteristics of three representative pyrolysis products of the organic matter of Middle and Upper Ordovician source rocks of lime-mud mound facies. The numbers represent the number of carbon.

could be defined as diluted Kukersite-type source rock. The pyrolysis products of this type of source rocks are typically characterized by a great deal of benzene series (Toluene, Xylene, trimethylbenzene) and compounds of 3 normal alkylbenzene series. Comparing with the Kukersite-type source rock, the carbon number distribution of normal alkane and normal olefine compounds are evidently expanded. The highest carbon number is up to $\mathrm{C}_{29}$. However, the overall abundance of high carbon number part is relatively low (Figure 5(b)). The relative contents of 5-N-alkyl-1,3-Benzenediol and homologous compounds are obviously decreased, sometimes to a level even undetectable (Figure 1(b)). Occasionally, there is algainite which is like G. prisca found in kerogen morphological organic matter. The vitrinite-like maceral is relatively rich. Although the benzene series could be formed through the condensation and dehydrogenation of polyenoic fatty acid, phytic acid or the ethylenic bonds in kerogen [29]. But it is commonly believed that the abnormally abundant benzene series and 3-N-alkylphenol series compounds are related with the input of the lignin and tannic acid material of terrestrial plants. This is a typical character of the pyrolysis products of organic matter in coal source rocks [30-32]. However, there were no terrestrial plants on earth during the Ordovician period. The sedimentary organic matters during that period were mainly contributed by marine plankton and benthos. It has been confirmed that the macromolecular structure of poly phenols in modern macro brown algaes could form phenolic compounds during the process of pyrolysis [33,34]. The systematic researches of chemical constituents (especially the carbohydrate, pigment, lipoid substance and phenolic compound) of modern benthic brown, red and green algaes also show that the essential components of the organic matter of modern benthic brown algaes are carbohydrates and phenolic compounds [35]. According to the detailed palaeobiology record of the Middle and Upper Ordovician sedimentary source rocks of lime-mud mound facies of the Tarim Basin, the sedimentary strata consists of macroalgae such as thallophyca, fasciculella, tawuia, isophylum, paleolaverilla, prototaxites(?) and juriaphyllum [36]. Therefore, it is surmised that the organic inputs of ancient macroalgae are the essential biogenic elements of the benzene series and phenolic compounds in pyrolysis products. The benthic macroalgae is possibly the main hydrocarbon generating material of such source rocks. Macroalgae is a hydrogendeficient benthic algae at the beginning, which determines the main characteristics of the species as follows: hydrogendeficiency in organic matter and gas generation. The third type of kerogen pyrolysis products of source rocks is characterized by an enrichment of normal alkane and normal olefine. Its distribution of carbon number could be $\mathrm{C}_{29}$ without odd-even predominance. Meanwhile, the content of benzene series is high, while those of alkylbenzene, alkylthrophene and phenol compounds are relatively low (Figure $5(c)$ ), which reflects the typical sedimentary character of a dominance of input of hydrogen-enriched organic matters such as phytoplangkton. This type of source rocks has high abundance of organic matter and is characterized by hydrogen 
enrichment. It is a type of high quality oil source rocks. As a matter of fact, the latter two source rocks correspond to the Middle and Upper Ordovician hydrocarbon generating organic matters defined by Wang Feiyu and his colleagues in accordance with the optical characteristics of rocks [36].

Based on the pyrolysis products of the above three source rocks, it is clear that the main difference between them is the different biological inputs. The main contributor of the first type of source rocks is G. prisca. The second type of source rock, to a great extent, is formed in the macroalgae and benthic algae development environment. The third type of source rocks shows a feature of hydrogen enrichment due to the increase of phytoplangkton input. Although there are controversial opinions, most researchers tend to believe that the G. prisca is a photoheterotrophic cyanobacteria [7,28, 37-39]. After a thorough investigation of the G. priscaenriched development environment of Ordovician sediments in Estonia, Foster and his colleagues $(1989,1990)$ believed that the $G$. prisca was mainly developed in intertidal zone $[6,40]$. In the meantime, modern ecology showed that the depth of water where macroalgae and benthic algae mainly inhabit was 30 to $60 \mathrm{~m}$. In view of the effective utilization of light by phytoplangkton, it is seen, the development of G. prisca is not sensitive to the depth of water. This fact can also be reflected in the lithologic characteristics of these three source rocks. The first and second types of source rocks are mainly biogenic limestone, which has been gradually changed into pelsparite in the third type of source rocks. It represents the increasing process of water depth (Table 1). Hence, the water depth strictly controlled the biologic development features in the sedimentary environment of the Middle and Upper Ordovician source rocks and ultimately controlled the organic characteristics, distribution and hydrocarbon generating potentials of all three types of source rocks.

\subsection{Development environment of $G$. Prisca and the inspiration on searching Kukersite-type source rocks in the Ordovician strata in the Tarim Basin}

Global exploration practices show that, the Ordovician source rocks with high abundance of organic matter, which is mainly contributed by $G$. prisca as the biogenic elements, are extensively distributed in today's North American, Australian and Northern European sedimentary basins, which means that $G$. prisca is massively bred in the marginal sea of tropic area in Ordovician period [12]. According to the results of paleomagnetic research, the Tarim Basin is in line with North American Platform and Northern Europe in Ordovician Period. Therefore, it possesses the geographic background for the breeding of G. prisca [41]. In the meantime, a large numbers of exploration and geological and geochemical researches show that the lime-mud mound discovered in the margin slope of platform of the Middle and Upper Ordovician in the Tarim Basin is the major hydrocarbon source of the Lower Paleozoic petroleum system.
However, this study has seriously analyzed the 11 representative samples from hundreds of the Middle and Upper Ordovician source rocks selected by fellow researchers [19]. The primary bases of sampling are the abundance of organic matter, the hydrogen index and the characteristics of morphological organic matter. As mentioned above, the Kukersite-type source rocks are only found in the typical Lianglitage Formation sediment at depth of $3960 \mathrm{~m}$ in Well Tazhong No.6 according to the results. On one hand, it indicates that G. prisca-enriched Kukersite-type source rocks could be developed in the Ordovician sediments of the Tarim Basin. On the other hand, it also shows that the G. prisca-enriched Kukersite-type source rocks could be developed only at local horizon due to the effect of water depth as well as hydrodynamic condition of sedimentary environment.

It is well known that the lime-mud mound could be developed in the inner table land (platform inner sag), platform margin and other low energy environment, especially the deepwater flat gradient environment with weak hydrodynamic conditions. In the mode of classic carbonate sedimentary facies, the lime-mud mound is intent to develop on the platform margin slope within the $120 \mathrm{~m}$ to over $300 \mathrm{~m}$ water depth in photic zone. According to the fine laminar algal, laminar birds eyelet or tent conglomerate on the massive and layered lime-mud mound of the hillock-top, the minimum water depth for lime-mud mound's development should be the intertidal zone, or sometimes the epilittoral zone. According to the ecological fact that the abundant benthic macroalgae (brown algae) is contained in the shale micrite of interdune depression, the maximum water depth for lime-mud mound's development should be $60 \mathrm{~m}$. This is because the modern marine algaes in $20-30 \mathrm{~m}$ water depth are brown algaes in principle. In the meantime, the brown algae contains great amounts of fucoxanthin and the effective light is yellow and orange lights. Therefore the brown algaes flourish in the water interval at depth of 30 to $60 \mathrm{~m}$ [42]. According to this, the possible main hydrocarbon generating materials of the Middle and Upper Ordovician source rocks of lime-mud mound facies deposited in the Tarim Basin are benthic macroalgae and phytoplangkton along with small amount of G. prisca, which is corresponding with the above mentioned second and third types of source rocks. The development of G. prisca-enriched Kukersite-type source rocks is small and scattered in the basin. Assuming that the crude oil from the Lower Paleozoic petroleum system is mainly contributed by the Middle and Upper Ordovician sedimentary source rocks of lime-mud mound facies of platform margin slope, the molecular geochemical features of the crude oil could not show the $G$. prisca biogenic characteristics.

\section{Conclusion}

(1) Through the kerogen pyrolysis-gas chromatography- 
mass spectrography analysis of moderate maturity source rock, this study confirmed that the $G$. prisca-enriched Kukersite-type source rocks indeed exist in the Middle and Upper Ordovician sediments of lime-mud mound facies in the Tarim Basin for the first time. The pyrolysis products show the following features: a low content of $>n-C_{19}$ chain hydrocarbon, an obvious odd-even predominance between $n-\mathrm{C}_{13}$ and $n-\mathrm{C}_{17}$, the isomers of alkylbenzene and alkylthrophene series replaced by normal long-chain alkyl, distinctive distribution of 5-N-alkyl-1,3-Benzenediol and homologous compounds and etc.

(2) According to the composition characteristics of the Kerogen pyrolysis products of source rocks, the Middle and Upper Ordovician sedimentary source rocks of lime-mud mound facies in the Tarim Basin can be divided into three types. The first type is the typical $G$. prisca-enrich Kukersite-type source rock. The second type is diluted Kukersite-type source rocks. The pyrolysis products of this type of source rocks are typically characterized by benzene series enrichment (Toluene, Xylene, trimethylbenzene) and 3 normal alkylbenzene series compounds. In addition, the biogenic element and organic matter are mainly macroalgae and hydrogen deficient and gas. The third type of source rocks is characterized by high abundance of normal alkanes and normal olefine, with hydrogen-enriched organic matters such as plankton as its main source. This type of source rocks is featured by a high abundance of organic matters, and is able to generate oils with high quality. The above mentioned three types of source rocks are mainly controlled by the water depth of sedimentary environment.

(3) Based on the breeding geographic environment characteristics of $G$. prisca and combining with the present revealed crude oil characteristics of the Lower Paleozoic petroleum system as well as the composition characteristics of kerogen pyrolysis products of the Middle and Upper Ordovician in the Tarim Basin, this study proposed that the possibility of a medium or large scale development of G. priscaenriched Kukersite-type source rocks in the major hydrocarbon source rocks of the Middle and Upper Ordovician in the Tarim Basin is small. Instead, the major developed source rocks should mainly be benthic macroalga and planktonic algae.

Thanks to Professor Zhang Baomin from Research Institute of Petroleum Exploration \& Development for providing samples' interpretation to sedimentary environment. The authors were extremely grateful for both reviewers' previous advices which improve this paper's quality. This work was supported by the National Oil and Gas Special Fund of China (2011ZX05008-002-15) and the National Natural Science Foundation of China (41172112).

1 Fowler M G, Douglas A G. Distribution and structure of hydrocarbon in four organic rich Ordovician rocks. Org Geochem, 1984, 6: 105114

2 Reed J D, Illich H A, Horsfield B. Biochemcal evolutionary significance of Ordovician oils and their sources. Org Geochem, 1986, 10:
$347-358$

3 Jacobson S R, Hatch J R, Teerrman S C, et al. Middle Ordovician organic matter assemblages and their effect on Ordovician-derived oils. AAPG Bull, 1988, 58: 499-506

4 Longman M W, Palmer S E. Organic geochemistry of Mid-Continent Middle and Late Ordovician oils. AAPG Bull, 1987, 71: 938-950

5 Foster C B, O'Brien G W, Waston S T. Hydrocarbon source potential of the Goldwyer Formation, Barbwire Terrace, Canning basin Western Ausrtalia. Aust Pet Expl Assoc J, 1986, 26: 142-155

6 Foster C B, Reed J D, Wicander R. Gloeocapsomorpha prisca Zalessky,1917: A new study part I: taxonomy geochemistry and paleoecology. Geobios, 1989, 22: 735-759

7 Hoffmann C F, Foster C B, Powell T G, et al. Hydrocarbon biomarkers from Ordovician sediments and fossil alga Gloeocapsomorpha prisca Zalessky 1917. Geochim Cosmochim Acta, 1987, 51: 2681-2697

8 Derenne S, Largeau C, Casadevall E, et al. Characterrization of Estonian kukersite by spectroscopy and pyrolysis: Evidence for abundant alkyl phenolic moieties in an Ordovician, marine, type II/I kerogen. Org Geochem, 1990, 16: 873-888

9 Macauley G, Fowler M G, Goodarzi F, et al. Ordovician oil shale-source rock sediments in the central and eastern Canada mainland and eastern Artic areas, and their significance for frontier exploration. Geol Surv Can Paper, 1990, 90: 14-51

10 Douglas A G, Sinninghe Damste J S, Fowler M G, et al. Unique distributions of hydrocarbons and sulphur compounds release by flash pyrolysis from the fossilised alga Gloeocapsomorpha prisca, a major constituent in one of four Ordovician kerogen. Geochem Cosmochim Acta, 1991, 55: 275-291

11 Douglas A G, Sinninghe Damste J S, de Leeuw J W, et al. Distribution and structure of hydrocarbons and heterocyclic sulfur compounds released from four kerogens of Ordovician age by means of flash pyrolysis. In: Schidlowski M, Golubic S, Kimberley M M, et al. Early Organic Evolution: Implications for Mineral and Energy Resources. Berlin: Springer, 1992. 267-278

12 Fowler M G. The influrence of Gloeocapsomorpha prisca on the organic geochemistry of oils and organic rich rocks of Late Ordovaican age from Canada. In: Schidlowski M, Golubic S, Kimberley M M, et al. Early Organic Evolution: Implications for Mineral and Energy Resources. Berlin: Springer, 1992. 336-356

13 Guthrie J M, Pratt L M. Geochemical character and origin of oils in Ordovician reservoir rock Illinois and Indiana USA. AAPG Bull, 1995, 79: 1631-1649

14 Hanson A D, Zhang S C, Moldowan J M, et al. Molecular organic geochemistry of the Tarim Basin, Northwest China. AAPG Bull, 2000, 84: 1109-1128

15 Zhang S C, Hanson A D, Moldowan J M, et al. Paleozoic oil-source rock correlations in the Tarim basin, NW China. Org Geochem, 2000, 31: $273-286$

16 Liang D G, Zhang S C, Zhang B M, et al. Understanding on marine oil generation in China based on Tarim basin (in Chinese). Front Earth Sci China, 2000, 7: 534-547

17 Zhang S C, Zhang B M, Wang F Y, et al. Middle-Upper Ordovician source rock geochemistry of the Tarim Basin (in Chinese). Mar Origin Pet Geol, 2000, 5:16-22

18 Zhang S C, Liang D G, Li M W, et al. Molecular fossils and oil-source rock correlations in Tarim Basin (in Chinese). Chin Sci Bull (Chin Ver), 2002, 47: 20-27

19 Zhang S C, Liang D G, Zhang B M, et al. The Generation of Marine Oil and Gas in Tarim Basin (in Chinese). Beijing: Petroleum Industry Press, 2004. 1-433

20 Wang T G, He F, Wang C, et al. Oil filling history of the Ordovician oil reservoir in the major part of the Tahe Oilfield, Tarim Basin, NW China. Org Geochem, 2008, 39: 1637-1646

21 Huang D, Liu B, Wang T, et al. Genetic type and maturity of Lower Paleozoic marine hydrocarbon gases in the eastern Tarim Basin. Chem Geol, 1999, 162: 65-77

22 Sun Y, Xu S, Lu H, et al. Source facies of the Paleozoic petroleum systems in the Tabei uplift, Tarim Basin, NW China: Implications from aryl isoprenoids in crude oils. Org Geochem, 2003, 34: 629-634 
23 Pan C, Liu D. Molecular correlation of free oil, adsorbed oil and inclusion oil of reservoir rocks in the Tazhong Uplift of the Tarim Basin, China. Org Geochem, 2009, 40: 387-399

24 Cai C, Li K, Anlai M, et al. Distinguishing Cambrian from Upper Ordovician source rocks: Evidence from sulfur isotopes and biomarkers in the Tarim Basin. Org Geochem, 2009, 40: 755-768

25 Li S, Pang X, Jin Z, et al. Petroleum source in the Tazhong Uplift, Tarim Basin: New insights from geochemical and fluid inclusion data. Org Geochem, 2010, 41: 531-553

26 Wang F Y, Chen J Y, Gao G, et al. Reflectance of macroalgaederived vitrinite-like macerals: An organic maturity indicator for pre-Devonian marine strata (in Chinese). Pet Explor Dev, 2010, 2: 250-256

27 Muscio G P A, Horsfield B, Welte D H. Compositional changes in the macromolecular organic matter (kerogen, asphltenes and resins) of a naturally matured source rock sequence from Northern Germany as revealed by pyrolysis methods. In: Abstract of 15th International Meeting of Organic Geochemistry. Manchester: Manchester University Press, 1992. 447-449

28 Blokker P, van Bergen P, Pancost R, et al. The chemical structure of Gloeocapsomorpha prisca microfossils: Implications for their origin. Geochim Cosmochim Acta, 2001, 65: 885-900

29 Larter S R, Horsfield B. Determination of structural compositions of kerogens using analytical pyrolysis methods. In: Engel M H, Macko S A, eds. Organic Geochemistry. New York: Plenum Press, 1990

30 Saiz-Jimenez C, De Leeuw J W. Lignin pyrolysis products: their structure and significance as biomarkers. Org Geochem, 1986, 10: 869-876

31 Saiz-Jimenez C, Boon J J, Hedge J I, et al. Chemical characterization of recent and buried woods by analytical pyrolysis: Comparison of pyrolysis data with C-NMR and wet chemical data. J Anal Appl Py- rolysis, 1987, 11: 437-450

32 Hactcher P G, Spiker E C. Selective degradation of plant biomolecules. Humic Substances and Their Roles in the Environments. New York: Wiley, 1988. 59-74

33 Ragan M A, Smidsro O, Larsen B. Chelation of divalent metal ions by brown algal polyphenols. Mar Chem, 1979, 7: 265-271

34 Ragan M A, Glombitza K W. Phlorotannins, brown algal polyphenols. In: Progress in Phycology Research. Bristol: Biopress, 1986. 129_ 241

35 Ji M H. Algae Chemistry (in Chinese). Beijing: Science Press, 1997. $1-777$

36 Wang F Y, Bian L Z, Zhang S C, et al. Two groups of organic matters in the Ordovician marine source rocks, the Tarim Basin (in Chinese). Sci China Ser D-Earth Sci, 2001, 54: 96-102

37 Zalessky J E. On marine sapropelite of Silurian age formed by a blue-green alga. Izv Imp Akad Nauk IV Ser, 1917, 1: 3-8

38 Stasiuk L D, Osadetz K G. The life cycle and phyletic affinity of Gloeocapsomorpha prisca Zalessky 1917 from Prdovician rocks in the Canadian Williston basin. Current Research Part D: Geol Surv Can, 1990, 89: 123-137

39 Stasiuk L D. Organic petrology and petroleum formation in Paleozoic rock of nothern Williston basin. Dissertation for the Doctoral Degree. Sasktcheman: University of Regina, 1991

40 Foster C B, Wicander R, Reed J D. Gloeocapsomorpha prisca Zalessky, 1917: A new study. Part II: Origin of Kukersite, a new interpretation. Geobios, 1989, 23: 133-140

41 Fang D J, Shen Z Y, Tan X D, et al. Paleomagnetism of Tarim Basin and the Plate Motion (in Chinese). Hangzhou: Zhejiang University Press, 2006. 1-364

42 Liu G Y. Marine Geography (Version 1) (in Chinese). Beijing: Beijing Normal University Press, 1989. 1-238

Open Access This article is distributed under the terms of the Creative Commons Attribution License which permits any use, distribution, and reproduction in any medium, provided the original author(s) and source are credited. 